\title{
STRATEGI MANAJEMEN SEBAGAI FAKTOR MITIGASI DALAM PENERIMAAN OPINI AUDIT \\ Studi Empirik pada Perusahaan Manufaktur di Indonesia
}

\author{
Olch \\ Widhy Setyowati \\ Universitas Stikubank Semarang \\ widhisetvowatiolagmail.com
}

\begin{abstract}
This research aims to provide empirical evidence upon the research questions proposed by conducting measurement of the hypothesis on the influence of the management strategy as mitigation factor in predicting the acceptance of GCO that involves financial based strategy such as sale of common stock strategy, issuing new debt or debt restructure, and sale of fixed asset. Whereas, non financial strategy that is expansionist and oriented to external market that will be studied as mitigation factor includes cooperative strategy or long term contract strategy and new product development strategy or expansion of new market segment.

The result show that the sale of common stock strategy and issuance of new debt or restructuring of debt strategy are the mitigation factors in acceptance of going concern opinion, whereas reducing cost strategy are perceived as additional going concern risk factors and increase the likelihood to receive a going concern opinion. Other strategies such as disposed fixed asset strategy, cooperation/long-term contracted strategy and development new product / expanding new market segments can not be used to predict the acceptance of going concern opinion.
\end{abstract}

Key words: going concern opinion, financial distress, management strategy, mitigation factor. 


\section{LATAR BELAKANG}

Laporan keuangan auditan berguna bag investor, calon investor dan pengguna lain dalam pengambilan keputusan ekonomi. Khususnya bagi investor, opini audit laporan keuangan merupakan pertimbangan penting dalam menentukan keputusan berinvestasi (Lev, 1989). Pemegang saham maupun pengguna laporan keuangan lainnya membutuhkan informasi tentang kemampuan perusahaan untuk melanjutkan usahanya (going concern) melalui opini auditor.

Pentingnya laporan audit yang berhubungan dengan going concern adalah untuk memberikan peringatan awal bagi pemegang saham dan pengguna laporan keuangan lainnya guna menghindari kesalahan dalam pembuatan keputusan (Mutchler, 1984). Opini going concern yang diterima perusahaan menunjukkan adanya kondisi dan peristiwa yang menimbulkan keraguan auditor akan kelangsungan hidup perusahaan, baik yang disebabkan karena kondisi keuangan maupun non keuangan. Oleh sebab itu manajemen akan berusaha untuk menghindari penerimaan opini going concern, yang terdiri dari opini wajar tanpa pengecualian dengan bahasa penjelas, opini wajar dengan pengecualian, opini tidak wajar dan tidak memberikan pendapat (Mutchler, 1986; Ramadhany, 2004; Rahayu,2006).

Selanjutnya, manajemen berusaha untuk mendapatkan opini wajar tanpa pengecualian (clean opinion) dengan melakukan berbagai rencana dan tindakan stratejik yang dapat mengurangi kemungkinan diterimanya opini going concern atau disebut sebagai faktor mitigasi dalam penerimaan opini going concern. Faktor mitigasi merupakan kondisi atau keadaan yang menunjukkan adanya berita baik atau good news yang dilakukan oleh perusahaan bermasalah untuk mengurangi ketidakpastian sehingga dapat menekan penerimaan opini going concern (Mutchler,1984;1985;1986; Mutchler et al.,1997)

Perusahaan yang menerima opini going concern dapat menurunkan harga sahamnya (Jones, 1996) yang berarti dapat menurunkan prestasi manajer karena harga saham dapat digunakan sebagai salah satu alat ukuran kinerja manajer. Disamping itu penerimaan opini going concern dapat berdampak terhadap kesulitan perusahaan untuk mencari pinjaman (Firth, 1980) maupun mempercepat perusahaan mengalami kebangkrutan atau self fulfilling prophecy (Mutchler, 1984; Hopwood et al., 1989).

Penelitian ini dimotivasi oleh Pernyataan Standar Auditing (PSA) No.30 Tahun 2001 yang menyatakan bahwa apabila terdapat keraguan yang besar tentang kemampuan satuan usaha dalam mempertahankan kelangsungan hidupnya (going concern) mengharuskan auditor untuk mengevaluasi rencana manajemen untuk mengatasi kondisi tersebut. Demikian pula beberapa perubahan telah dilakukan oleh kantor-kantor akuntan publik besar (Bell et al, 1997; Knechel, 2001; Curtis dan Turley, 2005 yang semula melakukan pendekatan audit tradisonal yang mengadopsi fokus bottom-up yang mengarahkan perhatian pada sifat rekening neraca, klasifikasi transaksi dan sistem akuntansi. Namun dalam perkembangannya auditing memperhatikan pula resiko bisnis yang mengembangkan perspektif holistic top-down dari bisnis dan industri klien, melalui analisis terhadap bisnis dan strategi klien.

Uraian tersebut diatas, didukung dengan literatur strategi bahwa dalam kondisi perusahaan mengalami financial distress akan melakukan pemulihan keadaan dengan melakukan strategi jangka pendek maupun jangka panjang (Hofer, 1980) yang dapat meningkatkan kinerja perusahaan. Rencana dan tindakan stratejik yang dapat dilakukan manajemen meliputi, rencana dan tindakan untuk emisi saham, menambah hutang baru atau melakukan restrukturisasi hutang, menjual aset tidak produktif dan mengurangi biaya (PSA 30, 2001; Behn et al.,2001). Selanjutnya strategi melakukan kerja sama termasuk perjanjian kontrak jangka panjang dan pengembangan produk baru termasuk membuka segmen pasar baru yang potensial merupakan tindakan stratejik yang berorientasi pada pertumbuhan jangka panjang dan difokuskan pada pasar eksternal (Capon et al., 1992).

Dengan demikian, peneliti menduga bahwa rencana dan tindakan stratejik yang dilakukan manajemen untuk memulihkan kondisi perusahaan yang sedang mengalami financial distress dapat mengurangi kemungkinan penerimaan opini going concern atau dapat dipandang sebagai faktor mitigasi dalam penerimaan opini going concern.

1. RERANGKA TEORITIS DAN PENGEMBANGAN HIPOTESIS 
2.1. Hubungan Strategi Saham dengan Opini Going Concern

Sudarsanam dan

Lai (2001)

menyatakan bahwa strategi berbasis ekuitas dengan melakukan penambahan modal pada perusahaan yang mengalami penurunan kinerja dapat meningkatkan kinerja perusahaan. Mutchler et al. (1997) memberikan bukti empiris bahwa management plans untuk mengeluarkan saham baru guna mengatasi kondisi buruk perusahaan merupakan good news yang menunjukkan adanya kredibilitas manajemen dalam mempertahankan kontinuitas perusahaan.

Demikian pula SAS 59 (1988) maupun PSA 30 (SPAP,2001) meminta auditor untuk mengevaluasi rencana manajemen untuk mengeluarkan saham baru, khususnya bagi perusahaan yang mengalami masalah going concern atau untuk perusahaan yang mengalami financial distress. Disisi lain strategi emisi saham merupakan viability strategy yang menunjukkan strategi untuk menjaga kelangsungan hidup perusahaan (LaSalle dan Anandarajan,1996)

Jika menurut pertimbangan auditor strategi tersebut efektif dan jumlahnya cukup signifikan untuk mengatasi kesulitan likuiditas paling tidak satu tahun yang akan datang dan diungkapkan dalam laporan keuangan sehingga dapat mengurangi keraguan auditor terhadap keberlangsungan perusahaan, maka auditor tidak akan memberi opini going concern (Bruynseels dan Willekens, 2006)

H1 : Strategi emisi saham baru merupakan faktor mitigasi dalam penerimaan opini going concern

2.2. Hubungan Strategi Hutang dengan Opini Going Concern

Ross (1977) bahwa perusahaan yang menarik hutang baru memberikan signal positif terhadap perusahaan karena memiliki kredibilitas sehingga mendapat kepercayaan dari pihak kreditor. Demikian pula Mutchler et al. (1997) bahwa penarikan pinjaman dan restrukturisasi hutang merupakan good news yang dipertimbangkan sebagai faktor mitigasi. Konsisten dengan hasil temuan Behn et al. (2001) dan Bruynseels dan Willekens (2006) yang membuktikan bahwa rencana manajemen untuk menarik kredit berpengaruh signifikan negatif terhadap penerimaan opini going concern.

Apabila strategi tersebut efektif mengatasi kesulitan keuangan maka hal ini akan mengurangi keraguan auditor atas kemampuan perusahaan melanjutkan usahanya maka auditor akan menunda untuk memberikan opini going concern (Bruynseels dan Willekens, 2006).

$\mathrm{H} 2$ : Strategi menambah hutang atau melakukan restrukturisasi hutang merupakan faktor mitigasi dalam penerimaan opini going concern.

2.3. Hubungan Strategi Menjual Aset Tidak Produktif dengan Opini Going Concern

Manajemen perlu melakukan strategi untuk mengatasi kondisi kesulitan keuangan karena adanya kewenangan yang diberikan pemegang saham untuk mengambil keputusan guna menjaga keberlangsungan usaha (Jensen dan Smith, 1984).

Salah satu usaha yang dapat dilakukan manajemen adalah menjual aktiva tidak produktif yang berasal dari divisi yang tidak menghasilkan, diharapkan dengan strategi tersebut perusahaan dapat memperkecil biaya operasi yang berupa biaya penyusutan maupun biaya pemeliharaan dan disisi lain pendapatan penjualan aktiva dapat digunakan untuk memperbaiki posisi keuangan perusahaan.

Uraian tersebut didukung oleh Sudarsanam dan Lai (2001) yang membuktikan bahwa perusahaan yang mengalami kondisi financial distress dapat melakukan pemulihan kondisinya dengan melakukan restrukturisasi aktiva dalam bentuk assets divestment.

SAS 59 (1988) dan PSA 30 (SPAP, 2001) secara eksplisit meminta auditor untuk mengevaluasi rencana manajemen untuk menjual aktiva tidak produktif bagi perusahaan yang mengalami financial distress yang selanjutnya dipertimbangkan dalam keputusan opini going concern. Strategi menjual aktiva tidak produktif menurut LaSalle dan Anandarajan (1996) merupakan viability strategy yang dapat dipertimbangkan auditor. Apabila strategi tersebut efektif dan dapat mengurangi keraguan auditor, maka strategi tersebut dapat mengurangi kemungkinan diterimanya opini going concern.

H3: Strategi menjual aset tidak produktif merupakan faktor mitigasi dalam penerimaan opini going concern

2.4. Hubungan Strategi Pengurangan Biaya dengan Opini Going Concern

Kondisi finncial distress mendorong manajer untuk melakukan strategi guna 
menghindari penerimaan opini going concern dengan melakukan pengurangan biaya, karena strategi ini merupakan salah satu strategi turnaround yang dapat memperbaiki kondisi financial distress (Pearce II et al., 2003).

Hal yang sama juga dikemukakan Pearce II et al. (2003) bahwa salah satu strategi turnaround yang dilakukan perusahaan adalah cost reduction yang meliputi pengadaan aktiva dengan cara leasing daripada membeli, memperpanjang umur mesin, mengurangi aktivitas promosi, memberhentikan sebagian pegawai, mengurangi jenis produk yang tidak menguntungkan dan memberhentikan penjualan kepada pelanggan yang memberi marjin rendah.

Disisi lain SAS 59 (1988) dan PSA 30 (SPAP,2001) memberi petunjuk bahwa rencana manajemen untuk melakukan pengurangan biaya perlu diungkapkan dalam penjelasan laporan keuangan termasuk rencana restrukturisasi pengurangan pengeluaran, rencana adanya tindakan pengurangan biaya dan gaji, penerapan pengurangan pegawai dan program pengurangan biaya lainnya yang diimplementasikan guna mengurangi biaya total operasi.

H4: Strategi pengurangan biaya merupakan faktor mitigasi dalam penerimaan opini going concern.

2.5. Hubungan strategi kerjasama atau kontrak jangka panjang dengan opini going concern.

Strategi kerjasama yang dilakukan manajemen merupakan salah satu strategi manajemen dalam upaya untuk memperoleh dukungan yang berkesinambungan dari mitra usaha baik pembeli, penjual maupun mitra usaha lainnya yang mendukung usaha perusahaan. Perusahaan yang mengalami distress dapat melakukan kerjasama atau kontrak jangka panjang sebagai bagian dari strategic twnaround (Hofer, 1980). Demikian pula Hitt et al. (2002) mengemukakan bahwa perusahaan dapat melakukan kerjasama dalam bentuk joint venture, aliansi strategis ekuitas dan aliansi strategis non ekuitas. Uraian tersebut didukung oleh penelitian Barker III \& Duhaime (1997) yang memberi bukti empiris bahwa strategi kontrak / kerjasama yang dilakukan dengan mitra perusahaan akan dapat meningkatkan kinerja jangka panjang perusahaan.
Lebih lanjut, Mitchel dan Singh (1996) membuktikan bahwa aliansi dapa meningkatkan tingkat survival organisasi. Dari penelitian-penelitian tersebut memberikan gambaran bahwa upaya perusahaan untuk melakukan kerjasama dengan pihak eksternal merupakan salah satu strategi untuk menjaga kelangsungan hidup organisasi. Oleh karena itu ketika auditor menghadapi perusahaan yang sedang mengalami financial distress perlu mempertimbangkan strategi viability yang dilakukan sebelum membuat keputusan opini (LaSalle dan Anandarajan, 1996).

Uraian tersebut didukung dengan adanya perubahan metodologi auditing yang telah dilakukan oleh beberapa kantor akuntan publik besar yang mengembangkan perspektif holistic top-down dari bisnis dan industri klien melalui analisis terhadap bisnis dan strategi klien (Bruynseels da Willkekens,2006). Apabila strategi tersebu dipandang efektif untuk mengatasi kesulitan keuangan perusahaan minimal dalam waktu satu tahun mendatang maka auditor akan menunda untuk memberikan opini going concern

H5 : Strategi melakukan kerjasama atau kontrak jangka panjang dapat mengurangi kemungkinan penerimaan opini going concern.

2.6. Hubungan strategi produk dengan opini going concern

Perusahaan yang mengalami distress dapat memperbaiki kondisinya dengan melakukan strategi jangka panjang yang berorientasi pada pasar eksternal, seperti mengeluarkan produk baru, meningkatkan mutu produk atau meningkatkan komposisi produk campuran untuk peningkatan penjualan. Uraian tersebut didukung oleh Bruton et al. (2003) bahwa perusahaan yang mengalami penurunan dapat melakukan pemulihan melalui pendekatan stratejik (strategic turnaround approach) yang bertujuan pada peningkatan profitabilitas jangka panjang seperti strategi pengembangan produk atau strategi membuka segmen pasar baru yang potensial.

Demikian pula Barker III dan Dukaime (1997) memberikan bukti empiris bahwa perusahaan yang mengalami distress dapat melakukan pemulihan dengan marketing changes melalui pengembangan produk baru atau pengembangan segmen pasar baru yang potensial. 
Strategi pengembangan produk baru dilakukan dengan melakukan perubahan secara substansial dari produk yang sudah ada atau menciptakan produk baru yang dapat dipasarkan pada pasar yang ada melalui saluran distribusi yang sudah berjalan. Strategi pengembangan produk juga sering dikaitkan dengan usaha memperpanjang daur hidup barang khususnya untuk barang yang memiliki merek yang handal dan reputasi tinggi (Pearce II et al., 2003).

Berkaitan dengan perkembangan pendekatan metodologi auditing yang bersifat top- down holistic dimana auditor dalam proses auditnya akan menganalisis strategi bisnis klien untuk mempertimbangkan resiko bisnis yang dihadapi maka strategi pengembangan produk baru merupakan strategi yang dapat dipertimbangkan oleh auditor pada saat membuat keputusan opini. Apabila auditor mempertimbangkan strategi tersebut efektif dilakukan sebagai upaya manajemen untuk menjaga kelangsungan hidup perusahaan maka auditor akan memberikan opini non going concern (Bruynseels dan Willekens, 2006).

H6 : Strategi pengembangan produk baru atau perluasan segmen pasar dapat mengurangi kemungkinan penerimaan opini going concern

2.7. Hubungan Variabel Kontrol dengan Keputusan Opini Going Concern

Keraguan yang besar terhadap kemampuan perusahaan untuk melanjutkan usahanya dapat ditunjukkan dengan terjadinya kegagalan keuangan (financial distress). Kondisi keuangan ditunjukkan dengan rasio lancar, rasio solvabilitas dan operating profit margin. Behn et.al (2001) dan Bruynseels dan Willekens (2006), membuktikan semakin baik kondisi keuangan semakin kecil kemungkinan menerima opini going concern.

Disisi lain terjadinya kegagalan hutang / debt default baik yang timbul karena perusahaan tidak mampu untuk memenuhi kewajibannya atau perusahaan tidak dapat memenuhi perjanjian hutang merupakan salah satu faktor yang dapat mempengaruhi keputusan opini going concern oleh auditor (Chen dan Church, 1992).

Auditor akan lebih sering mengeluarkan opini going concern bagi perusahaan yang lebih kecil (Mutchler, 1986), dengan alasan bahwa perusahaan besar akan lebih mudah mengatasi masalah keuangan karena memiliki jajaran manajemen yang lebih baik sehingga pihak kreditor akan lebih bisa percaya untuk memberikan kredit kepada perusahaan besar, kondisi ini diperhatikan auditor untuk menunda memberikan opini going concern. Lebih lanjut dapat dijelaskan karena pemberian opini going concern dapat mengakibatkan jatuhnya perusahaan /selffulfilling prophecy effect (Mutchler, 1984) maka auditor akan menunda untuk memberikan opini going concern.

Pemakai laporan keuangan lebih percaya pada laporan keuangan auditan yang diaudit oleh auditor yang dianggap berkualitas tinggi dibanding auditor yang kurang berkualitas. Anggapan tersebut disampaikan karena untuk mempertahankan reputasinya auditor akan lebih berhati-hati dalam melakukan proses audit untuk mendeteksi salah saji, kecurangan, atau melakukan penilaian dalam menghadapi masalah ketidak pastian. Mutchler et al. (1997) menemukan bukti bahwa auditor Big 6 lebih cenderung mengeluarkan opini going concern pada perusahaan yang mengalami financial distress. Lebih lanjut, Geiger dan Raghunandan (2002) membuktikan bahwa KAP besar lebih banyak mengeluarkan opini going concern dibandingkan KAP kecil.

\section{Metode Penelitian}

\subsection{Populasi dan Sampel}

Populasi penelitian ini adalah perusahaan manufaktur yang terdaftar di Bursa Efek Indonesia (BEI) dengan mengacu pada perusahaan-perusahaan manufaktur yang termuat di Indonesian Capital Market Directory (ICMD) tahun 2007 - 2011. Obyek penelitian adalah perusahaan manufaktur yang listing di Bursa Efek Indonesia (BEI) dari tahun 2006 sampai tahun 2010 sejumlah 759 perusahaan. Selanjutnya sampel ditentukan dengan metode purposive sampling, dengan kriteria sebagai berikut (a) menerbitkan laporan keuangan yang lengkap, (b) menerbitkan laporan keuangan yang telah diaudit oleh auditor independen dari tahun 2006 - 2010 , (c) mengalami masalah financial distress.

3.2. Operasionalisasi dan pengukuran variabel

3.2.1.Variabel dependen.

Variabel dependen dalam penelitian ini merupakan variabel dummy, untuk opini going concern (GCO) diberi kode 1 dan untuk opini wajar tanpa pengecualian (clean opinion) yang dalam penelitian ini disebut opini non going-concern diberi kode 0

3.2.2. Variabel Independen 
Variabel independen terdiri dari Strategi Emisi Saham, Strategi Hutang, Strategi menjual aktiva tidak produktif, Strategi Pengurangan Biaya, Strategi Kerjasama atau Kontrak jangka panjang dan Strategi Pengembangan Produk Baru. Semua variabel independen merupakan variabel dummy, jika perusahaan membuat rencana atau melaksanaka

\begin{tabular}{|l|l|}
\hline & \\
& \\
\hline CACL & \\
LTDTA & \\
NIBTS & \\
SIZE & \\
Valid N & \\
\hline
\end{tabular}

$N$
75
75
75
75

n strategi-strategi tersebut diberi kode 1 dan jika tidak diberi kode 0 .

\subsubsection{Variabel Kontrol}

Variabel kontrol dalam penelitian ini menggunakan (1) likuiditas, diukur dengan rasio aktiva lancar dibagi hutang lancar, (2) solvabilitas, diukur dengan Rasio hutang jangka panjang dibagi total aktiva, (3) profitabilitas, diukur dengan net profit margin yaitu rasio laba bersih sebelum pajak dibagi dengan total penjualan, debt default kegagalan hutang

Ukuran perusahaan, diukur dengan logaritma total aset, Reputasi auditor.

(6)

\subsection{Teknik analisis}

\begin{tabular}{|c|c|c|c|c|}
\hline & \multicolumn{3}{|c|}{ FREQUENCY } & \multicolumn{2}{c|}{ PERCENT } \\
\hline & $\begin{array}{c}\text { Nilai } \\
\text { O(dummy) }\end{array}$ & $\begin{array}{c}\text { Nilai } \\
\text { I(dummy) }\end{array}$ & $\begin{array}{c}\text { Nilai } \\
\text { 0(dummy) }\end{array}$ & $\begin{array}{c}\text { Nilai } \\
\text { 1(dummy) }\end{array}$ \\
\hline Opini & 161 & 114 & 58,5 & 41,5 \\
\hline Default & 187 & 88 & 68,0 & 32,0 \\
\hline KAP & 115 & 160 & 41,8 & 58,2 \\
\hline S-Modal & 191 & 84 & 69,5 & 30,5 \\
\hline S-Hutang & 99 & 176 & 36,0 & 64,0 \\
\hline S-Aktiva & 137 & 138 & 49,8 & 50,2 \\
\hline S-Biaya & 99 & 176 & 36,0 & 64,0 \\
\hline S-Kontrak & 104 & 171 & 37,8 & 62,2 \\
\hline S-Produk & 134 & 141 & 48,7 & 51,3 \\
\hline
\end{tabular}

4.2. Pengujian Hipotesis

Pengujian hipotesis dalam penelitian ini menggunakan regresi logistik dan sebelumnya perlu dilakukan uji asumsi klasik dalam bentuk uji multikolonieritas, hasilnya menunjukkan korelasi yang lebih kecil dari 0.9 atau tidak terjadi multikol antar variabel independen. .

Hasil pengujian fit model Hosmer Lemeshow diketahui bahwa Chi-Square sebesar 3.881 dengan df 8 dan tingkat signifikansi .868 . Level signifikansi tersebut lebih besar dari .05 yang berarti bahwa model mampu memprediksi nilai observasinya atau dapat dikatakan bahwa model penelitian ini adalah model yang sudah fit.

Statistik -2LogL menunjukkan model dengan konstanta saja sebesar 373.159 apabila konstanta ditambah variabel bebas -

4. Analisis Data dan Pembahasan

4.1. Statistik Deskriptif 
2LogL menjadi 88.942. Hasil tersebut menunjukkan adanya penurunan $-2 \mathrm{LogL}$, penurunan tersebut pada binary logistic menunjukkan bahwa penambahan variabel independen membuat model menjadi lebih baik.

Nilai Negelkerke $R$-square yang diinterprestasikan seperti nilai $R$ square pada multiple regression sebesar .868 artinya bahwa variasi variabel independen dapat menjelaskan kemungkinan penerimaan opini going concern sebesar $86,8 \%$. Hasil tersebut didukung oleh hasil regresi logistik dalam tabel klasifikasi yang menunjukkan estimasi yang benar untuk perusahaan sampel yang menerima opini going concern (GCO) sebesar $86,0 \%$ atau secara keseluruhan tingkat ketepatan prediksi sebesar $91,6 \%$.

Tabel 4.3 berikut untuk menjelaskan pengujian hi[potesis 1 sampai 6

Tabel 4.3 .
CACL + 3.984 LTDTA - 4.555 NIBTS + 23.171 DEFAULT - .616 SIZE $-.081 \mathrm{KAP}+\mathrm{e}$ a. Pembahasan Hipotesis 1

Hasil pengujian membuktikan strategi emisi saham signifikan (sig .040) dan memiliki koefisien regresi bertanda negatif (1.543). Hal ini menunjukkan bahwa perusahaan yang mengalami financial distress dan melakukan strategi emisi saham akan lebih kecil kemungkinannya menerima opini going concern atau strategi manajemen untuk emisi saham merupakan faktor mitigasi dalam penerimaan opini going concern.

Penerimaan hipotesis tersebut mendukung konsep keagenan, oleh karenanya, pada saat perusahaan mengalami kesulitan keuangan maka manajemen akan melakukan upaya untuk emisi saham agar memiliki tambahan dana yang dapat digunakan untuk memperbaiki posisi likuiditas maupun memperbaiki kondisi

\begin{tabular}{|c|c|c|c|c|}
\hline & B & Wald & Sig, & $\operatorname{Exp}(\mathrm{B})$ \\
\hline S Modal & -1.543 & 4.205 & .040 & .214 \\
\hline S Hutang & -1.954 & 10.125 & .001 & .142 \\
\hline S Aktiva & -.562 & .828 & .363 & .570 \\
\hline S Biaya & 2.097 & 7.530 & .006 & 8.145 \\
\hline S Kontrak & -.156 & .070 & .791 & .855 \\
\hline S Produk & .852 & 1.707 & .191 & 2.344 \\
\hline CACL & -2.256 & 10.952 & .001 & .105 \\
\hline LTDTA & 3.984 & 7.399 & .007 & 53.714 \\
\hline NIBTS & -4.555 & 6.657 & .010 & .011 \\
\hline DEFAULT & 23.171 & .000 & .995 & $1.2 \mathrm{E}+010$ \\
\hline SIZE & -.616 & .830 & .362 & .540 \\
\hline KAP & -.081 & .017 & .897 & .922 \\
\hline Constant & 2.775 & .532 & .466 & 16.033 \\
\hline $\begin{array}{l}\text { Cox \& Snell } \\
\text { R Square }\end{array}$ & \multicolumn{4}{|l|}{.644} \\
\hline \multirow[t]{2}{*}{$\begin{array}{l}\text { Nagelkerke } \\
\text { R Square }\end{array}$} & \multicolumn{4}{|l|}{.868} \\
\hline & \multicolumn{2}{|c|}{ Chi-square } & Df & Sig \\
\hline $\begin{array}{l}\text { Hosmer and } \\
\text { Lemeshow } \\
\text { Test }\end{array}$ & \multicolumn{2}{|c|}{3.881} & 8 & .868 \\
\hline
\end{tabular}

ekuitas negative sehingga dapat mengurangi keraguan auditor atas kemampuan perusahaan untuk usahanya. melanjutkan Temuan empiris tersebut juga mendukung Pernyataan Standar Auditing No. 30 (SPAP, 2001) paragraf 7 huruf $d$ dan konsisten dengan hasil penelitian Sudarsanam dan Lai (2001), Behn et al. (2001) yang membuktikan bahwa rencana manajemen untuk emisi saham

Hasil Regresi logistik dengan yariabel kontrol

Sumber : Data diolah

Persamaan regresi logistik sesuai tabel 4.3 untuk kepentingan analisis lebih lanjut, tampak sebagai berikut :

$$
\begin{aligned}
& \mathrm{Ln} \frac{\mathrm{GCO}}{1-\mathrm{GCO}}=2.775-1.543 \mathrm{~S} \text { Modal }-1.954 \mathrm{~S} \\
& \text { Hutang }-.562 \mathrm{~S} \text { Aktiva }+2.097 \mathrm{~S} \text { Biaya - } \\
& .156 \mathrm{~S} \text { Kontrak }+.852 \mathrm{~S} \text { Produk }-2.256
\end{aligned}
$$

menunjukkan hasil signifikan negative dalam menjelaskan penerimaan opini going concern. Strategi ini menunjukkan adanya kredibilitas manajemen untuk memperoleh kepercayaan dari pemegang saham (LaSalle dan Anandarajan, 1996).

\section{b. Pembahasan Hipotesis 2}

Hasil pengujian hipotesis membuktikan bahwa strategi hutang berpengaruh signifikan negative terhadap kemungkinan penerimaan opini going concern, oleh karenanya pada 
perusahaan financial distress manjemen dapat melakukan strategi hutang guna mengurangi kemungkinan penerimaan opini going concern.

Temuan penelitian ini mendukung konsep yang dikemukakan oleh Gilson (1990) bahwa restrukturisasi hutang merupakan transaksi yang merubah kontrak hutang dengan kontrak baru yang memiliki satu atau lebih karakteristik (1) mengurangi bunga atau pokok pinjaman, (2) memperpanjang jatuh tempo, (3) merubah hutang menjadi ekuitas. Beban yang semakin berkurang tersebut dapat menekan tingkat financial distress sehingga pada kondisi tertentu dapat mengurangi keraguan auditor akan kemampuan perusahaan untuk melanjutkan usahanya dan dapat berakibat tidak diberikannya opini going concern

Hasil penelitian ini juga mendukung penelitian Mutchler $(1985 ; 1986)$, Mutchler et al. (1997) dan Behn et al. (2001) yang membuktikan bahwa strategi menarik pinjaman menunjukkan hasil yang signifikan negatif. Konsisten dengan temuan empirik LaSalle dan Anandarajan (1996) bahwa strategi hutang menunjukkan adanya kepercayaan pihak eksternal terhadap perusahaan atau menunjukkan adanya kredibilitas manajemen yang selanjutnya dapat dipertimbangkan dalam penentuan opini audit.

c. Pembahasan hipotesis 3

Hasil pengujian regresi logistik membuktikan bahwa hipotesis 3 tidak terbukti walaupun koefisien regresi menunjukkan tanda negative, seperti yang dihipotesiskan. Penolakan hipotesis 3 mengindikasikan bahwa penjualan asset yang tidak produktif pada perusahaan yang mengalami financial distress dipandang sebagai upaya pemulihan jangka pendek yang tidak mampu memberikan perubahan dalam perusahaan (Schendel et al., 1976; Hofer, 1980, Barker III dan Duhaime, 1997). Temuan empiris tersebut juga didukung oleh penelitian Behn et al, (2001) yang menguji rencana manajemen sebagai mitigating factor hasilnya tidak signifikan.

Tidak diterimanya hipotesis 3 memberi petunjuk bahwa auditor memandang strategi untuk menjual asset merupakan strategi jangka pendek yang tidak menjamin kontinuitas perusahaan dalam waktu satu tahun mendatang sehingga tidak mengurangi keraguan auditor akan kemampuan perusahaan untuk melanjutkan usahanya dan selanjutnya tidak mempengaruhi penerimaan opini going concern.

\section{d. Pembahasan hipotesis 4}

Hasil regresi logistik memberikan bukti empiris bahwa tingkat signifikansi variabel tersebut lebih kecil dari $5 \%$ dengan koefisien regresi bertanda positif. Hasil penelitian tersebut membuktikan bahwa strategi pengurangan biaya berpengaruh secara signifikan terhadap penerimaan opini going concern. Hasil koefisien regresi menunjukkan tanda positif, hal ini mengindikasikan bahwa strategi pengurangan biaya tidak berfungsi sebagai faktor mitigasi tetapi justru meningkatkan kemungkinan penerimaan opini going concern atau disebut sebagai contrary information.

Temuan penelitian ini didukung dengan hasil penelitian Bruynseels dan Willekens (2006) yang membuktikan bahwa strategi pengurangan biaya yang meliputi pengurangan biaya operasi maupun pemberhentian pegawai bukan merupakan mitigating factor tetapi justru memperkuat adanya indikasi bahwa perusahaan sedang menghadapi masalah going concern dan berdampak pada meningkatnya kemungkinan penerimaan opini going concern.

\section{e. Pembahasan hipotesis 5}

Hasil pengujian hipotesis 5 tidak terbukti, penolakan hipotesis tersebut dikarenakan bahwa kerjasama yang dilakukan oleh perusahaan manufaktur yang digunakan sebagai sampel dalam penelitian ini dapat dikelompokkan menjadi (1) kerjasama yang membawa konsekuensi fee bagi perusahaan, yang mewajibkan perusahaan membayar biaya tertentu kepada perusahaan lain, (2) kerjasama yang berdampak pada hasil jangka panjang, seperti kerjasama usaha kemitraan dengan kelompok pembeli untuk menjaga stabilitas pasar produk maupun dengan penjual untuk menjaga pasokan bahan baku, kerjasama pengelolaan usaha.

Kerjasama tersebut tidak memberikan dampak langsung kepada perusahaan untuk mengatasi kesulitan keuangan. Dengan demikian, kedua jenis strategi kerjasama yang dilakukan manajemen tersebut tidak dapat mengurangi keraguan auditor atas kemampuan perusahaan untuk melanjutkan usahanya sehingga tidak dapat berpengaruh terhadap kemungkinan penerimaan opini going concern.

f. Pembahasan hipotesis 6 
Hasil pengujian empiris menunjukkan bahwa hipotesis 6 tidak terbukti atau strategi manajemen untuk mengeluarkan produk baru atau memperluas segmen pasar tidak berpengaruh terhadap kemungkinan penerimaan opini going concern. Dengan demikian pengembangan produk yang dilakukan perusahaan tidak dapat memberikan dampak yang dapat digunakan untuk mengatasi kesulitan keuangan perusahaan yang mengalami financial distress.

Tidak diterimanya hipotesis tersebut dikarenakan dalam kondisi perusahaan mengalami kesulitan keuangan (financial distress) masih terbebani dengan biaya pemasaran yang cukup besar untuk memasarkan produk baru. Alasan tersebut memberikan indikasi bahwa strategi untuk mengembangkan produk baru atau memperluas segmen pasar tidak dapat mengurangi keraguan auditor atas kemampuan perusahaan untuk menjaga kelangsungan usahanya, yang selanjutnya tidak dipertimbangkan sebagai faktor mitigasi dalam penerimaan opini going concern.

\section{g. Pembahasan variabel kontrol.}

Hasil regresi logistik variabel kontrol kondisi keuangan yaitu likuiditas, solvabilitas dan profitabilitas ketiganya menunjukkan hasil signifikan, hal ini memberikan makna bahwa semakin baik kondisi keuangan perusahaan akan mengurangi kemungkinan penerimaan opini going concern. Hasil penelitian ini konsisten dengan temuan Mutchler (1985), Chen dan Church (1992) dan Behn et al.(2001). Dari hasil penelitian tersebut menunjukkan bahwa auditor dalam memberikan opini audit pada perusahaan yang mengalami financial distress akan memperhatikan kondisi keuangan.

Hasil pengujian variabel debt default tidak signifikan, hal ini berarti bahwa terjadinya kegagalan hutang pada suatu perusahaan tidak berpengaruh secara langsung terhadap penerimaan opini going concern karena auditor lebih mempertimbangkan ketiga rasio keuangan yaitu likuiditas, solvabilitas dan profitabilitas.

Hasil pengujian empiris pengaruh skala perusahaan terhadap kemungkinan penerimaan opini going concern tidak signifikan, hal ini membuktikan bahwa skala perusahaan tidak berpengaruh terhadap kemungkinan penerimaan opini going concern. Hasil penelitian konsisten dengan temuan Ramadhany (2004). Temuan empiris dalam penelitian ini mengindikasikan bahwa auditor dalam memutuskan opini yang diberikan lebih banyak menggunakan ukuran keuangan dibandingkan ukuran perusahaan.

Hasil regresi logistik reputasi auditor tidak signifikan, hal ini dapat dijelaskan bahwa kantor akuntan publik besar akan mempertahankan reputasinya dengan menjaga independensinya selama melakukan audit (Shockly, 1981). Hasil penelitian ini tidak mendukung penelitian sebelumnya tetapi justru mendukung penelitian keprilakuan Messier (1983) bahwa partner bukan Big-Eight atau auditor skala kecil memiliki materialitas yang rendah dibandingkan partner Big-Eight, yaitu auditor skala kecil lebih berkeinginan untuk mengungkapkan masalah yang ada termasuk masalah going concern.

5.1. Simpulan

Manajer sebagai agen yang dberikan kepercayaan oleh prinsipal perlu melakukan berbagai strategi untuk memperoleh opini audit wajar tanpa pengecualian atau opini non going concern, dalam kondisi perusahaan mengalami financial distress, manajer perlu melakukan strategi saham dan hutang karena kedua strategi tersebut merupakan faktor mitigasi. Sedangkan strategi menjual aktiva tidak produktif tidak mempengaruhi penerimaan opini going concern, sebaliknya strategi pengurangan biaya justru merupakan contrary factor yang dapat memperbesar kemungkinan penerimaan opini going concern. Demikian pula strategi kerjasama dan strategi produk yang berorientasi pada peningkatan kinerja jangka panjang tidak efektif untuk menghindari kemungkinan penerimaan opini going concern.

Variabel likuiditas, solvabilitas dan profitabilitas merupakan variabel kontrol yang signifikan untuk menguji hubungan strategi manajemen terhadap kemungkinan penerimaan opini going concern, sedangkan debt default, ukuran perusahaan dan reputasi auditor tidak signifikan.

\subsection{Implikasi Hasil}

Implikasi teoritis, hasil penelitian ini dapat memperkuat penelitian sebelumnya tentang variabel -variabel yang mempengaruhi keputusan opini going concern, khususnya variabel strategi emisi saham dan strategi hutang sedangkan variabel strategi aktiva dan biaya perlu diteliti lebih lanjut. Demikian pula strategi yang berorientasi pada peningkatan kinerja jangka 
panjang seperti strategi kerjasama dan strategi produk perlu penelitian lebih lanjut.

Implikasi praktis, hasil penelitian ini dapat digunakan sebagai acuan bagi auditor agar lebih cermat dalam memperhatikan strategi yang dilaksanakan menajemen dalam mengatasi kesulitan keuangan perusahaan. Dengan demikian, manajemen perlu menjaga kondisi rasio likuiditas, solvabilitas dan profitabilitas dan mengupayakan berbagai strategi untuk mengatasi kesulitan keuangan perusahaan sehingga manajemen dapat menghindari penerimaan opini going concern.

Implikasi kebijakan, khususnya bagi pemegang saham dan calon kreditur, hasil penelitian ini diharapkan dapat memberikan warning bahwa opini going concern yang diterima perusahaan merupakan sinyal adanya keraguan auditor akan kelangsungan usaha perusahaan. Disamping itu opini yang diterima perusahaan dapat digunakan untuk mengevaluasi kinerja manajer agar manajemen dapat memperbaiki kondisi keuangan tahun berikutnya.

5.3. Keterbatasan Penelitian dan Rekomendasi Penelitian Berikutnya

Penelitian ini menguji rencana manajemen dalam mengatasi kesulitan keuangan sesuai PSA 30 (SPAP,2001), yang secara eksplisit menyatakan bahwa sebelum membuat keputusan opini going concern, auditor perlu memperhatikan rencana manajemen untuk mengatasi kesulitan keuangan yang ada. Disarankan penelitian berikutnya dapat menggunakan data primer guna menggali rencana strategi manajemen yang belum diungkapkan dalam laporan keuangan.

\section{DAFTAR PUSTAKA}

AICPA. 1988. Reports of Audited Financial Statements. Statement on Auditing Standards No.58. Auditing Standards Board (ASB).

AICPA. 1988. The Auditor's Considerations of an Entity's Ability to Continue as a GoingConcern. Statement on Auditing Standards No.59. Auditing Standards Board (ASB).

Barker III, V.L.,dan L.M.Duhaime .1997. "Strategic change in the turnaround process : theory and empirical evidence". Strategic Management Journal. 18(1), 13-38.
Behn., Steven E Kaplan dan K.R.Krunwiede, 2001."Further Evidence on the Auditor's Going-Concern Report : The Influence of Management Plans". Auditing : Journal of Practice and Theory. March. Vol 20. No.I.

Bruton, G.D., D.Ahlstrom dan J.Wan, 2003 "Turnaround in East Asian Firms: Evidence from Ethnic Overseas Chinese Communities". Strategic Management Journal. 24(6), 519-540.

Bruynseels, Liesbeth dan Marleen Willekens. 2006. Strategic Viability and Going-Concern Auidit Opinion.

Marleen.willekens@econ.kuleuven.be

Capon, N., J.U.Farley, D.R. Lehman dan J.M.Hubert, 1992. "Profile of product innovators among large US Manufacturers". Management Science. 38(2).157-169

Chen, K. C. W. dan B. K. Church. 1992. "Default on debt obligations and the issuance of opini going Concern". Auditing: a. Journal of Practice and Theory. 11(2): 11-23.

Fanny,M. dan Saputra,S. 2005. "Opini Audit Going Concern: Kajian Berdasarkan Model Prediksi Kebangkrutan, Pertumbuhan Perusahaan dan Reputasi Kantor Akuntan Publik ( Studi pada Emiten Bursa Efek Jakarta)". SNA VIII. Solo.

Firth, M. 1978. "Qualified Audit Reports: Their Impact on Investment Decisions". The Accounting Review. Vol 53 No.3. July : 642650

Geiger, M.A., dan K.Raghunandan. 2002. "GoingConcern Opinions in the 'New' Legal Environment". Accounting Horizons. Vol 16. No.1. March : 17-26

Ghozali, I. 2006. Analisis Multivariate Lanjutan dengan Program SPSS. Third Edition. Badan Penerbit Universitas Diponegoro Semarang.

Hanafi,M. 2003. Manajemen Keuangan. BPFE. Yogyakarta,

Hofer,C.W. 1980. "Turnaround Strategies". Journal of Business Strategy . 1(1), 19-31.

Hopwood, W., J. McKeown dan J. Mutchler. 1989, "A test of the Incremental explanatory power of opinions qualified for consistency and uncertainty". The Accounting Review. January : $28-48$

Ikatan Akuntan Indonesia (IAI). 2001. Pertimbangan Auditor Atas Kemampuan Satuan Usaha Dalam Mempertahankan Kelangsungan Hidupnya, PSA No. 30, Standar Profesional Akuntan Publik (SPAP). Jakarta.

Jones. F. L. 1996. "The Information Content of the Auditor's Going Concern Evaluation". Journal of Accounting and Public Policy. Spring. 1-27 
LaSalle, R.E., dan A.Anandarajan, 1996. "Auditor's view on the type of audit report issued to entities with going concern uncertainties". Accounting Horizons. 10 (June): 51-72

Lev.B.1989. "On the Usefulness of Earnings Research: Lessons and Discussion from Two Decade Empirical Research". Journal of Accounting Research. 27 (Supplement). Pp 152-201

Mishina, Y., Pollock, T.G., dan J.Porac.2004. "Are more resources always better for growth ? Resource stickiness in market and product expansion". Strategic Management Journal. 25(12).1179-1197.

Mutchler, 1985. "A multivariate analysis of the auditor's going concern opinion decision". Journal of Accounting Research. 23(2), 66882.

1997. "The Influence of Contrary, Information's and Mitigating Factors: on Audit Opinion Decision on Bankrupt Companies" . Journal of Accounting Research. Vol. 35. No. 2. Autumn, pp 295310
Pearce II., John.A.Robinson, dan Richard.B. 2003. Strategic Management : Formulation, Implementation and Control. Eight Edition. Mc.Graw-Hill Companies,Inc. New York.

Rahayu,P. 2006. Assesing Going Concern Opinon : A Study Based on Financial and Non Financial Information (Empirical Evidence of Indonesian Banking Firms Listed on JSX and SSX). Thesis. Master of Science in Accounting Post Graduate Program of Diponegoro University. Tidak dipublikasikan.

Ramadhany. Alexander. 2004. "Analisis Faktor-faktor yang Mempengaruhi Penerimaan Opini Going Concern pada Perusahaan Manufaktur yang Mengalami Financial Distress di Bursa Efek Jakarta". Jurnal Maksi. Vol.4. Agustus.

Ross,S., 1977. "The Determination of financial structure : The Incentive signaling approach". Bell Journal of Economics. 8. 23-40.

Sudarsanam,S. dan J.Lai. 2001. "Corporate Financial Distress and Turnaround Strategies : An Empirical Analysis". British Journal of Management. 12 (3), 183-199. 